\title{
Polysaccharide composition of Ecklonia stolonifera Okamura and their enzymatic hydrolysis
}

\author{
Yoji Kato ${ }^{1}$, Shinichiro Odagiri ${ }^{1}$, Kenichi Teraoka ${ }^{2}$ and Yukihiro Ito $^{2}$ \\ ${ }^{1}$ Laboratory of Food Science, Faculty of Education, Hirosaki University, \\ 1 Bunkyo-cho, Hirosaki, Aomori, 036-8560 Japan \\ Fax: 81-0172-39-3436, e-mail: ykato@,cc.hirosaki-u.ac.jp \\ ${ }^{2}$ Oma fishermen's cooperative, \\ Oma-machi, Shimokita-gun, Aomori, 039-4601 Japan
}

\begin{abstract}
Tsuruarame (Ecklonia stolonifera Okamura) belongs to Laminariaceae which is representative of brown algae. Tsuruarame is removed from sea area of Oma, Aomori Prefecture because of a bad influence on the production of Makonbu (Laminaria japonica Areschoug). In order to obtain the fundamental information for effective use of the removed Tsuruarame, the polysaccharide composition of Tsuruarame and their enzymatic hydrolysis were investigated. Sugar composition analysis suggested that laminaran, fucoidan, and cellulose were the types of polysaccharides present in the cell-walls of Tsuruarame, and that the carbohydrates in Tsuruarame and Makonbu had features in common. Commercial enzymes for the effective saccharification of Tsuruarame polysaccharides were screened for. Meicellase $P$ was selected. The amount of glucose released from the $4 \% \mathrm{KOH}$-pretreated, triturated Tsuruarame by treatment with Meicellase $\mathrm{P}$ accounted for about $40-50 \%$ of glucan in Tsuruarame

Key words: Tsuruarame, Seaweed, Brown algae, Polysaccharides
\end{abstract}

\section{INTRODUCTION}

Many studies have been conducted to develop new manufacturing techniques for use of biomass resources. Seaweed is one of the biomass resources. Tsuruarame (Ecklonia stolonifera Okamura) is removed from sea area of Oma, Aomori Prefecture because of inhibition of the growth of Makonbu (Laminaria japonica Areschoug). It is very important to use the removed Tsuruarame effectively.

Tsuruarame and Makonbu belong to Laminariaceae which is representative of brown algae. Although numerous studies on Makonbu polysaccharides have been done [1], characterization of the component polysaccharides of Tsuruarame is not clear. Information on the polysaccharide composition of Tsuruarame is very useful for enzymatic saccharification. Commercial enzymes for the effective saccharification of Tsuruarame polysaccharides were screened for.

\section{MATERIAL AND METHOD}

\section{2-1. Materials}

Tsuruarame was collected in December 2003 in Omamachi, Aomori, and dried in the sun. Makonbu was purchased from a supermarket at Hirosaki, Aomori. The dried-Tsuruarame and Makonbu were separately chopped into slices and triturated in a mill.

\section{2-2. Determination of total sugar contents and acidic sugar contents}

Total sugar and acidic sugar contents in each sample were determined by the phenol-sulfuric acid method [2] and the carbazole-surfuric acid method [3], respectively.

\section{2-3. Neutral sugar composition analysis}

Analysis of neutral sugars in oligo- or poly-saccharide fraction was carried out by the high-performance anion exchange chromatography (HPAEC) with pulsed amperometric detection (PAD), Dionex ion chromato- graphy system DX-300 [4] after hydrolysis of each sample with acid. The retention times of peaks of each sample were compared with those of standard sugars, fucose (Fuc.), arabinose (Ara.), rhamnose (Rha.), galactose (Gal.), glucose (Glc.), xylose (Xyl.) and mannose (Man.).

\section{2-4. Gel filtration chromatography on Bio-Gel P-2}

Each sample was applied to a column $(1.0 \times 30 \mathrm{~cm})$ of Bio-Gel P-2 followed by filtration through the column with water; $0.5-\mathrm{ml}$ fractions were collected and assayed for carbohydrates by the phenol-sulfuric acid method.

\section{2-5. Saccharification of Tsuruarame by commercial} enzyme preparations

The following commercial enzyme preparations were used for this study. Cellulase $\mathrm{T}$ Amano (Amano Enzyme), Hemicellulase Amano 90 (Amano Enzyme), Cellulosine HC100 (HBI Enzyme), Cellulosine TP25 (HBI Enzymes), Cellulosine PE60 (HBI Enzymes), Cellulosine T2 (HBI Enzymes), Toyocellulase (Toyo Jozo), Cellulase Onozuka 3S (Yakult Pharmaceutical), Cellulase Y-NC (Yakult Pharmaceutical), $\alpha$-Amylase type IIIA (Nakarai tesque), UNIASE R (Yakult Pharmaceutical), Meicellase (Meiji), Cellulosine ME (HBI Enzymes), Cellulosine AC40 (HBI Enzymes), Cellulase Amano 3 (Amano Enzyme), Cellulosine PC5 (HBI Enzymes), Celluosine AF (HBI Enzymes), Cellulosine HC (HBI Enzymes), Cellulase AP-3 (Amano Enzyme), Meicellase $P$ (Meiji), MACERATING S (Yakult Pharmaceutical), Cellulase Type II (SIGMA), Glucanase, Kitalase $200 \mu \mathrm{l}(\mathrm{K} \cdot \mathrm{I}$ Chemical), Kitalase $450 \mu \mathrm{l}(\mathrm{K} \cdot \mathrm{I}$ Chemical), Pectinase (Toyo Jozo), Sucrase (Sankyo Lifetech), and Sanzyme 1000 (Sankyo Lifetech). Each enzyme (dry weight, $50 \mathrm{mg}$ ) was dissolved in $5 \mathrm{ml}$ of water and centrifuged to remove insoluble materials. The supernatant were used as enzyme solutions after 
determination of sugar contents by the phenol-sulfuric acid method.

The triturated Tsuruarame ( $50 \mathrm{mg}$ ) was suspended in water $(5 \mathrm{ml})$ and mixed with the individual enzyme solution $(0.25 \mathrm{ml})$. Each mixture was incubated for $48 \mathrm{hr}$ at $40^{\circ} \mathrm{C}$ in the presence of a few drops of toluene. Separately, the triturated Tsuruarame $(50 \mathrm{mg})$ suspended in $3 \mathrm{ml}$ of $4 \% \mathrm{KOH}$, was stirred for $24 \mathrm{hr}$ at room temperature and neutralized with acetic acid. Water was added to the neutralized solution. The resulting solution (final volume, $5 \mathrm{ml}$ ) was incubated for $48 \mathrm{hr}$ at $40^{\circ} \mathrm{C}$ with the individual enzyme solution $(0.25 \mathrm{ml})$ in the presence of a few drops of toluene. After incubation, the reaction mixture was centrifuged for $30 \mathrm{~min}$ at 3,000 rpm. Sugar content of the supernatant was determined by the phenol-sulfuric acid method. The amount of released sugar was calculated according to the equation; the amount of released sugar $=$ (the amount of released sugar by treatment with each enzyme) - (the amount of released sugars by treatment without enzyme) - (the amount of sugar in each enzyme)

2-6. Fractionation of carbohydrate in the triturated Tsuruarame and treatment of the obtained fractions with Meicellase $P$

Figure 1 shows a flow-chart for the fractionation of carbohydrate in the triturated Tsuruarame and treatment of the obtained fractions with Meicellase P. The triturated Tsuruarame $(500 \mathrm{mg})$ was extracted with 25 $\mathrm{ml}$ of water for $12 \mathrm{hr}$. The extract was designated as water-soluble fraction. The residue of the extraction with water (water-insoluble fraction) was treated with $25 \mathrm{ml}$ of $4 \% \mathrm{KOH}$ for $24 \mathrm{hr}$ at room temperature. The extract was neutralized with acetic acid to give $4 \% \mathrm{KOH}$ soluble fraction. The residue of the extraction with $4 \%$ $\mathrm{KOH}$ was neutralized with acetic acid to give $4 \% \mathrm{KOH}$ insoluble fraction. Each fraction was incubated for $48 \mathrm{hr}$ at $40^{\circ} \mathrm{C}$ with Meicellase P. Then each fraction was centrifuged to remove the insoluble material. The appropriate volume of the supernatant was subjected to gel filtration on Bio-Gel P-2. Carbohydrate was assayed by the phenol-sulfuric acid method.

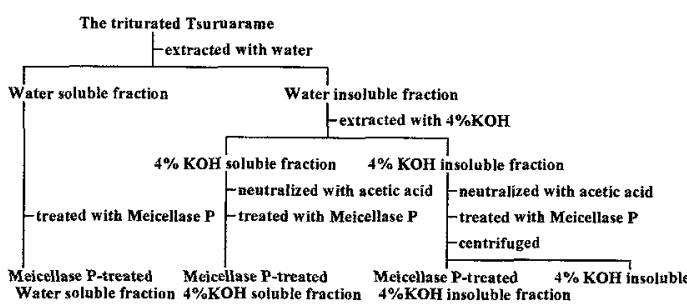

Fig.1. Flow-chart for the fractionation of carbohydrates in the triturated Tsuruaram and treatment of the obtained fractions with Meicellase P.

2-7. Influence of the concentration of substrate and enzyme, and the temperature on hydrolysis of the triturated Turuarame with Meicellase $P$

The triturated Tsuruarame $(50 \mathrm{mg}$ ) suspended in $4 \%$ $\mathrm{KOH}(3 \mathrm{ml}, 1.5 \mathrm{ml}$, and $0.6 \mathrm{ml})$ was stirred for $24 \mathrm{hr}$ at room temperature and neutralized with acetic acid $(0.1$ $\mathrm{ml}, 0.06 \mathrm{ml}$, and $0.03 \mathrm{ml})$. Water $(1.9 \mathrm{ml}, 0.94 \mathrm{ml}$, and $0.37 \mathrm{ml}$ ) was added to the neutralized solution. The resulting solution was incubated for $48 \mathrm{hr}$ at $40^{\circ} \mathrm{C}$ with Meicellase $\mathrm{P}(0.25 \mathrm{ml})$ in the presence of a few drops of toluene.

The triturated Tsuruarame (50 mg) suspended in $4 \%$ $\mathrm{KOH}(1.5 \mathrm{ml})$ was stirred for $24 \mathrm{hr}$ at room temperature and neutralized with acetic acid $(0.06 \mathrm{ml})$. Water $(0.94$ $\mathrm{ml}$ ) was added to the neutralized solution. The resulting solution was incubated for $48 \mathrm{hr}$ at $40^{\circ} \mathrm{C}$ with Meicellase $P(0.125 \mathrm{ml}, 0.25 \mathrm{ml}$, and $0.5 \mathrm{ml})$ in the presence of a few drops of toluene.

The triturated Tsuruarame $(50 \mathrm{mg}$ ) suspended in $4 \%$ $\mathrm{KOH}(1.5 \mathrm{ml})$ was stirred for $24 \mathrm{hr}$ at room temperature and neutralized with acetic acid $(0.06 \mathrm{ml})$. Water $(0.94$ $\mathrm{ml}$ ) was added to the neutralized solution. The resulting solution was incubated for $48 \mathrm{hr}$ at $40^{\circ} \mathrm{C}, 30^{\circ} \mathrm{C}$, and 20 ${ }^{\circ} \mathrm{C}$ with Meicellase $\mathrm{P}(0.125 \mathrm{ml})$ in the presence of a few drops of toluene.

After incubation, each reaction mixture was centrifuged for $30 \mathrm{~min}$ at $3,000 \mathrm{rpm}$. The supernatant was subjected to gel filtration chromatography on BioGel P-2. Carbohydrate was assayed by the phenolsulfuric acid method. The ratio of monosaccharide contents (MS) and total sugar contents (TS) in the soluble material of enzyme-treated Tsuruarame was calculated.

\section{RESULTS AND DISCUSSION}

3-1. Comparative analysis of total sugar contents and sugar composition between Tsuruarame and Makonbu

The triturated Tsuruarame and Makonbu were separately hydrolyzed by treatment with conc. sulfuric acid. The total sugar contents (as Glc equiv.) and acidic sugar contents (as GalUA equiv.) in the hydrolyzates were determined by the phenol-sulfuric acid method and the carbazole-sulfuric acid method, respectively. Total sugar contents and acidic sugar contents were $222.8 \mathrm{mg}$ and $313.4 \mathrm{mg}$ per $1 \mathrm{~g}$ dry weight for Tsuruarame, and $137.6 \mathrm{mg}$ and $262.4 \mathrm{mg}$ per $1 \mathrm{~g}$ dry weight for Makonbu. Neutral sugar composition analysis of the hydrolyzates was done by HPAEC-PAD. The ratio of Fuc, Ara, Rha, Gal, Glc, Xyl and Man was 8.4:0.4:0.1:5.1:81.5:0.8:3.9 for Tsuruarame, and 12.6:0.5:0:7.1:75.8:0.8:3.4 for Makonbu. Glucose was detected as the major neutral monosaccharide. Although a large number of possible polysaccharide can be deduced from the data, reference to previous works of Makonbu would suggest that laminaran, fucoidan, cellulose were the types of polysaccharides present in the cell-walls of Tsuruarame. It is apparent from the data presented here that the carbohydrate in Tsuruarame and Makonbu has features in common.

In addition, the triturated Tsuruarame and Makonbu were separately treated with water to afford watersoluble and water-insoluble fractions. Total sugar contents and total acidic sugar contents in each fraction were determined. Total sugar and acidic sugar contents in water-soluble and water-insoluble fractions of Tsuruarame (1g dry weight) were $57.8 \mathrm{mg}$ and $49.9 \mathrm{mg}$, and $120.8 \mathrm{mg}$ and $231.5 \mathrm{mg}$, respectively, and total sugar and acidic sugar contents in water-soluble and water-insoluble fractions of Makonbu (1g dry weight) were $16.8 \mathrm{mg}$ and $30.9 \mathrm{mg}$, and $165 \mathrm{mg}$ and $263.5 \mathrm{mg}$, respectively. There is a high possibility that the content 
of polysaccharides in Tsuruarame is higher than that in Makonbu.

\section{3-2. Saccharification of Tsuruarame by commercial enzyme preparations}

An experiment was conducted to determine whether or not commercial enzyme preparations were useful for saccharification of the cell-wall polysaccharides of Tsuruarame. The triturated Tsuruarame was treated exhaustively with 29 kinds of commercial enzyme preparations before and after treatment with $4 \% \mathrm{KOH}$.

Table I. The amount of released carbohydrate from the triturated Tsuruarame by commercial enzyme preparations before and after pre-treatment with $4 \%$ $\mathrm{KOH}$

\begin{tabular}{|c|c|c|}
\hline Enzymes name (manufacturer) & \begin{tabular}{|} 
Released carbo \\
before treatment \\
with $4 \% \mathrm{KOH}$ \\
\end{tabular} & \begin{tabular}{|l|} 
ofydrate $(\mathrm{mg})$ \\
after treatment \\
with $4 \% \mathrm{KOH}$ \\
\end{tabular} \\
\hline Cellulase T Amano (Amano Enzyme) & 0.0 & 0.0 \\
\hline Hemicellulase Amano90 (Amano Enzyme) & 0.6 & 3.8 \\
\hline Cellulosine HCl00 (HBI Enzymes) & 0.7 & 3.2 \\
\hline Cellulosine TP25 (HBI Enzymes) & 0.0 & 0.7 \\
\hline Cellulosine PE60 (HBI Enzymes) & 0.0 & 3.8 \\
\hline Cellulosine T2 (HBI Enzymes) & 1.1 & 4.6 \\
\hline Toyocellase (Toyo Jozo) & 0.5 & 4.9 \\
\hline Cellulase ${ }^{\text {onozuka.3S (Yakult Pharmaceutical) }}$ & 0.0 & 4.1 \\
\hline Cellulase Y-NC (Yakult Pharmaceutical) & 1.0 & 4.2 \\
\hline a-amylase Type II $\cdot \mathrm{A}($ Nakarai tesque) & 0.0 & 0.0 \\
\hline UNIASE R (Yakult Pharmaceutical) & 0.0 & 1.5 \\
\hline Meicellase (Meiji) & 1.0 & 3.8 \\
\hline Cellulosine ME (HBI Enzymes) & 0.5 & 1.2 \\
\hline Cellulosine $\mathrm{AC} 40$ (HBI Enzymes) & 0.4 & 2.7 \\
\hline Cellulase Amano 3 (Amano Enzyme) & 0.6 & 1.3 \\
\hline Cellulosine PC5 (HBI Enzymes) & 0.7 & 1.0 \\
\hline Cellulosine AF (HBI Enzymes) & 0.0 & 0.0 \\
\hline Cellulosine HC (HBI Enzymes) & 2.6 & 4.5 \\
\hline Cellulase AP-3 (Amano Enzyme) & 1.4 & 3.1 \\
\hline Meisellase P (Meiji) & 2.8 & 5.7 \\
\hline MACERATING S (Yakult Pharmaceutical) & 1.2 & 3.4 \\
\hline Cellulase Type II (SIGMA) & 0.0 & 0.6 \\
\hline Cellulosine AP (HBI Enzymes) & 0.0 & 0.0 \\
\hline Glucanase & 0.0 & 0.0 \\
\hline Kitalase $200 \mu 1$ (K·I Chemical) & 1.5 & 3.4 \\
\hline Kitalase $450 \mu 1$ (K-1 Chemical) & 0.3 & 1.0 \\
\hline Pectinase (Toyo jozo) & 0.2 & 3.7 \\
\hline Sucrase (Sankyo Lifetech) & 1.6 & 2.8 \\
\hline Sanzyme 1000 (Sankyo Lifetech) & 3.0 & 3.4 \\
\hline
\end{tabular}

As shown in Table $I$, the released carbohydrate increased by $\mathrm{KOH}-$ treatment. The amount of released carbohydrate is highest in the case of Meicellase P-treatment. Approximately $5.7 \mathrm{mg}$ carbohydrates were released from the $50 \mathrm{mg}$ triturated Tsuruarame.

The molecular weight distribution of the released materials was determined by gel filtration on Bio-Gel P-2. Figure 2 shows the elution profiles of the carbohydrate extracted with water from triturated Tsuruarame, and that of the carbohydrate released from the triturated Tsuruarame by treatment with Meicellase $\mathrm{P}$ after pretreatment with $4 \% \mathrm{KOH}$, respectively. Fractions I, II and III obtained in Fig. 2-(2) and the residues obtained after the enzyme treatment were subjected to neutral sugar composition analysis. The result is shown in Table II. It is clear that fraction III (Fr. III) in Fig. 2-(2), which corresponds to the elution position of monosaccharide, was produced from the component polysaccharide of Tsuruarame by the enzyme treatment. This fraction is rich in glucose and the amount of glucose $(4.5 \mathrm{mg})$ accounts for about $9 \%$ of Tsuruarame (dry weight, 50 $\mathrm{mg}$ ).
(1)

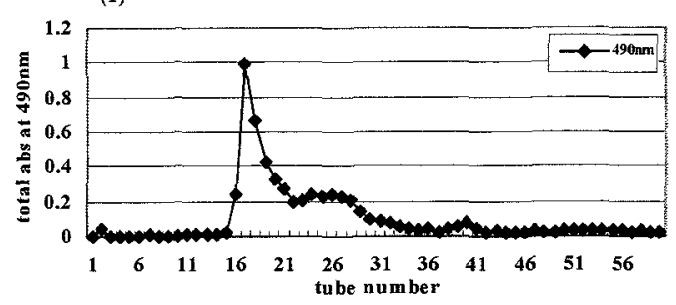

(2)

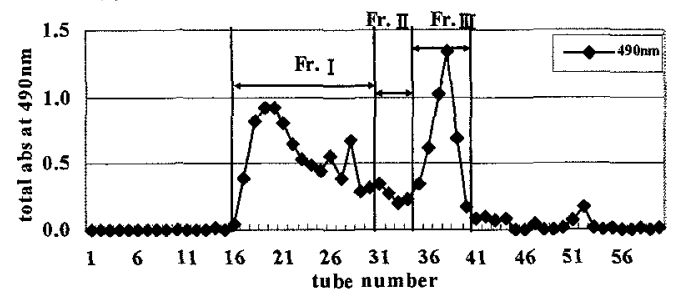

Fig.2. Bio-Gel P-2 chroamtography of the carbohydrate extracted with water from the triturated Tsuruarame (1), and that of the carbohydrate released from the triturated Tsuruarame by treatment with Meicellase $\mathrm{P}$ after the pretreatment with $4 \% \mathrm{KOH}(2)$.

Table II. Neutral sugar composition of fractions I, II and III obtained in Fig. 2-(2)

\begin{tabular}{ccccccccc}
\hline \multirow{2}{*}{ Fraction } & Ratio & \multicolumn{7}{c}{ Sugar Composition (\%) } \\
& (\%) & Fuc. & Ara. & Rha. & Gal. & Glc. & Xyl. & Man. \\
\hline I & 47.7 & 19.3 & 8.7 & 2.7 & 30.0 & 12.4 & 11.7 & 15.3 \\
II & 7.7 & 30.2 & 5.1 & - & 11.3 & 43.2 & 4.5 & 5.7 \\
III & 27.0 & - & 1.3 & - & 3.7 & 93.7 & 1.3 &. \\
\hline
\end{tabular}

3-3. Fractionation of carbohydrate in the triturated Tsuruarame and treatment of the obtained fractions with Meicellase $P$

As shown in Fig. 1, carbohydrates in the triturated Tsuruarame were fractionated into the water-soluble, $4 \%$ $\mathrm{KOH}$ soluble, and $4 \% \mathrm{KOH}$ insoluble fractions. The $4 \%$ $\mathrm{KOH}$-soluble and -insoluble fractions were neutralized with acetic acid. Each fraction was treated with Meicellase P. In order to investigate the molecular weight distribution, the enzyme-treated fractions were subjected to gel filtration on Bio-Gel P-2.

Figure 3 shows the elution profiles of the Meicellase P-treated water-soluble fraction, Meicellase P-treated $4 \% \mathrm{KOH}$-soluble fraction and the soluble material of Meicellase P-treated $4 \% \mathrm{KOH}$-insoluble fraction, respectively. Each monosaccharide fraction obtained in Figs. 3-(1), -(2), and -(3) were subjected to the sugar composition analysis. Glucose was not detected in the monosaccharide fraction of Meicellase P-treated $4 \%$ KOH-soluble fraction (Fig. 3-(2)).

The total amount of glucose released from triturated Tsuruarame can be estimated to be at least $56 \mathrm{mg}$ by summing up the amounts of glucose $(12.1 \mathrm{mg})$ in the monosaccharide fraction of Meicellase P-treated watersoluble fraction and of glucose $(43.9 \mathrm{mg})$ in the soluble material of Meicellase P-treated $4 \% \mathrm{KOH}$-insoluble fraction. The amount of total released glucose accounts for about $11.0 \%$ of Tsuruarame (dry weight, $500 \mathrm{mg}$ ).

This result suggests that there is no marked difference in the yield of glucose obtained by treatment with 
Meicellase $\mathrm{P}$ of $4 \% \mathrm{KOH}-$ pretreated Tsuruarame (above experiment 3-2) and the total glucose obtained by treatment with Meicellase $\mathrm{P}$ of the fractions prepared from Tsuruarame.

(1)

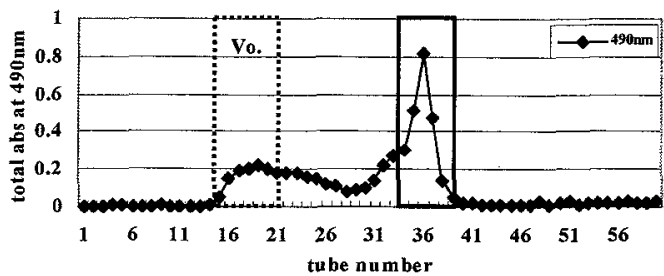

(2)

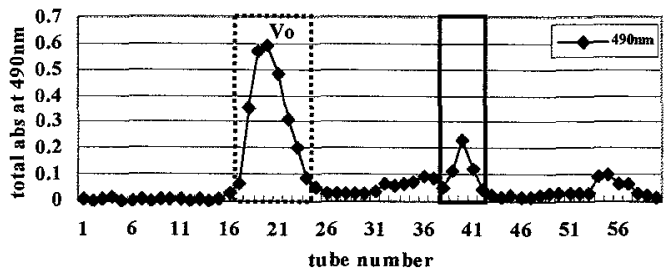

(3)

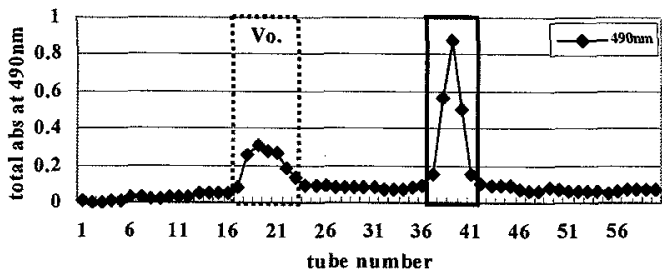

Fig.3. Bio-Gel P-2 chromatography of the Meicellase P-treated water-soluble fraction (1), Meicellase P-treated $4 \% \mathrm{KOH}$-soluble fraction (2) and the soluble material of Meicellase P-treated 4\% $\mathrm{KOH}$-insoluble fraction (3), respectively.

3-4. Influence of the concentrations of substrate and enzyme, and the temperature on hydrolysis of the triturated Turuarame with Meicellase $P$

From a viewpoint of industrial production of glucose from Tsuruarame, the influence of the concentration of substrate and enzyme on hydrolysis of Tsuruarame with Meicellase $\mathrm{P}$ was investigated. The triturated Tsuruarame was treated with Meicellase P for $48 \mathrm{hr}$ under the various conditions. Each sample was subjected to gelfiltration on Bio-Gel P-2 to separate the produced monosaccharide and others (Fig. 4). From peak areas, the ratios of monosaccharide contents (MS) and total sugar contents (TS) in the soluble material of enzymetreated Tsuruarame was calculated.

The ratios of MS/TS in the cases of $1 \%$ substrate concentration $(50 \mathrm{mg} / 5 \mathrm{ml}), 2 \%$ substrate concentration $(50 \mathrm{mg} / 2.5 \mathrm{ml})$, and $5 \%$ substrate concentration (50 $\mathrm{mg} / 1 \mathrm{ml}$ ) were $37 \%, 42 \%$ and $32 \%$, respectively.

The ratios of MS/TS of the cases of $0.125 \mathrm{ml}$ enzyme concentration $(6.25 \mathrm{mg}), 0.25 \mathrm{ml}$ enzyme concentration $(12.5 \mathrm{mg})$, and $0.5 \mathrm{ml}$ enzyme concentration $(25 \mathrm{mg})$ were $42 \%, 37 \%$, and $39 \%$, respectively.

The ratios of MS/TS of the cases of $40^{\circ} \mathrm{C}, 30^{\circ} \mathrm{C}$, and $20^{\circ} \mathrm{C}$ were $42 \%, 44 \%$, and $40 \%$, respectively.
From a viewpoint of industrial production of glucose from Tsuruarame, the reaction condition by Meicellase $P$ is established on the basis of above results as follows: the triturated Tsuruarame (50 mg) is suspended in $4 \%$ $\mathrm{KOH}(1.5 \mathrm{ml})$, and the suspension is neutralized with acetic acid $(0.06 \mathrm{ml})$, and mixed with water $(0.94 \mathrm{ml})$ and Meicellase $(6.25 \mathrm{mg}$ in $0.125 \mathrm{ml}$ water). The resulting reaction mixture is incubated for $48 \mathrm{hr}$ at $30^{\circ} \mathrm{C}$.

(1)

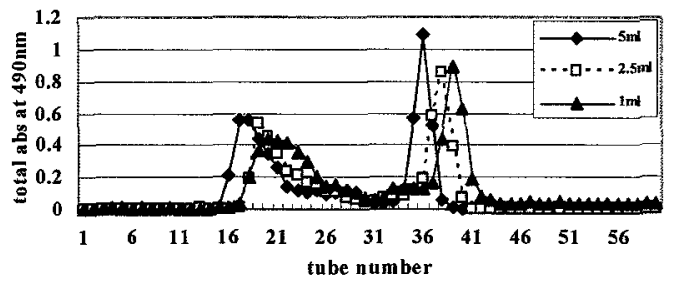

(2)
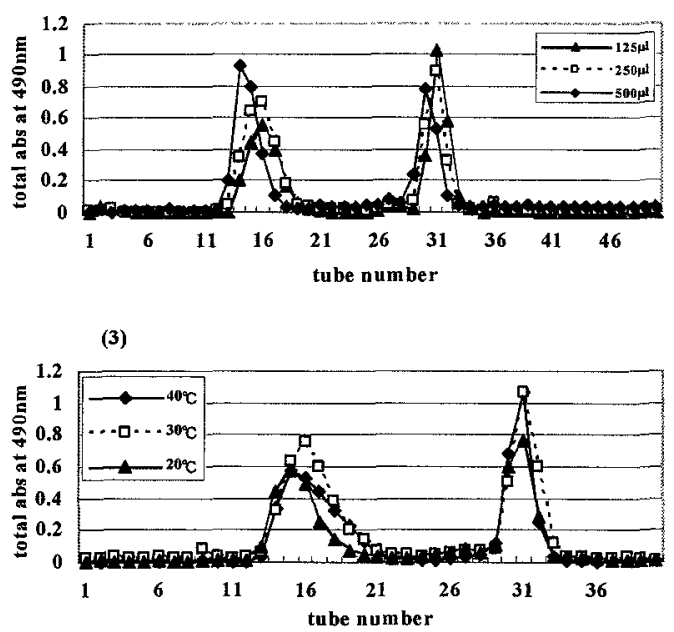

Fig.4. Bio-Gel P-2 chromatography of the released carbohydrates from the triturated Tsuruarame by hydrolysis with Meicellase $P$ under the various conditions.

(1) Substrate concentration: $50 \mathrm{mg} / 5 \mathrm{ml}, 50 \mathrm{mg} / 2.5 \mathrm{ml}$ and $50 \mathrm{mg} / 1 \mathrm{ml}$. (2) Enzyme concentration: $0.125 \mathrm{ml}$, $0.25 \mathrm{ml}$ and $0.5 \mathrm{ml}$. (3) Reaction temperature: $40^{\circ} \mathrm{C}$, $30^{\circ} \mathrm{C}$, and $20^{\circ} \mathrm{C}$.

\section{REFERENCES}

[1] "Sougou Tatourui Kagaku Ge", Ed. by T. Harada and A. Misaki, Kodansha (1974).

[2] M. Dubois, K.A.Gilles, J.K. Hamilton, P.A. Rebers and F. Smith, Anal. Chem., 28, 350-356 (1956).

[3] T. Bitter and H.M. Muir, Anal. Biochem., 4, 330-334 (1962).

[4] T. Konishi, Y. Mitsuishi and Y. Kato, Biosci. Biotechnol. Biochem., 62, 2421-2424 (1998).

(Received February 16. 2007;Accepted July 12, 2007) 